\title{
FOOD SAFETY AND SECURITY IN ROMANIA - AN ECONOMETRIC ANALYSIS IN THE CONTEKT OF NATIONAL AGRICULTURAL PARADIGM TRANSFORMATION
}

\author{
Mihaela Cristina Drăgoi ${ }^{1 *}$, Jean Vasile Andrei ${ }^{2}$, Mihai Mieilă $\breve{3}^{3}$, Mirela Panait ${ }^{4}$, \\ Carmen Elena Dobrotă ${ }^{5}$ and Raluca Georgiana Lădaru ${ }^{6}$ \\ ${ }^{1) 5) 6)}$ The Bucharest University of Economic Studies, Bucharest, Romania \\ ${ }^{2) 4)}$ Petroleum-Gas University of Ploiești, Ploiești, Romania \\ 3) Valahia University of Târgoviște, Târgoviște, Romania
}

\section{Please cite this article as:}

Drăgoi, M.C., Andrei, J.V., Mieilă, M., Panait, M., Dobrotă, C.E. and Lădaru, R.G., 2018. Food Safety and Security in Romania - An Econometric Analysis in the Context of National Agricultural Paradigm Transformation. Amfiteatru Economic, 20(47), pp. 134-150.

\section{Article History}

Received: 28 September 2017

Revised: 11 October 2017

Accepted: 9 November 2017:

\begin{abstract}
Food safety represents a current topic, with significant implications and diverse approaches within the specialized literature. In the context of globalization and integration of agricultural markets, the necessity of guaranteeing food safety is imperative for the functionality of contemporary agricultural systems. The radical transformation of the national agricultural systems as a result of the influences imposed by the convergence with the requirements and directions of the European agricultural model entails a significant change for the markets of agri-food products, affecting the food trade, its structure and, implicitly, food safety. In this context, the main objective of the present paper is to examine food safety in Romania using an econometric approach to the phenomenon. Nine fundamental variables are considered, for which the causal relationship between food safety and the exogenous variables taken into analysis is tested. The time frame for data availability for all the variables is 1990-2011. The obtained results highlight the transformations of paradigm of the national agricultural model from the perspective of the dimensions regarding food safety, confirming results from previous studies.
\end{abstract}

Keywords: food safety, food security, agricultural paradigm, econometric approach, food availability, agri-food production, food supply variability, Romania.

JEL Classification: O13, Q11, Q17, Q18.

*Corresponding author, Mihaela Cristina Drăgoi - mihaelacristina.dragoi@gmail.com 


\section{Introduction}

Addressing the complex issues of food safety requires understanding of the global transformations of the agricultural sector, both in terms of convergence with the European agricultural model and of national peculiarities, in the context of achieving a sustainable level of agri-food production, in order to ensure the availability, independence and sufficiency of food resources for population. Therefore, agriculture, through its classical functions, is essential not only in terms of providing the necessary nutritional resources for the population, but in the context of global economy transformations, due to the effects of the financial crisis, population growth, or difficult and limited access to energy resources, it must adapt to the new strategic, economic, social and environmental challenges imposed by the change of global agricultural paradigm. From this perspective, the new agricultural paradigm affirms food safety and security as fundamental pillars of the European agricultural model.

In this context, agriculture represents an economic branch with specificities and developments that do not comply with the classical economic laws, at least from the perspective of production and prices. Ensuring food safety and food security in a modern and highly functional market economy implies not only the availability of adequate food and resources for food production but also the availability of sufficient financial resources for the population in order to purchase food. Consequently, contemporary food systems are the result of agricultural transformation as an effect of agricultural policies and reforms promoted over time in order to increase the level of food safety and security. As noted in the specialised literature (Andrei and Darvasi, 2012; Turek Rahoveanu A. and Turek Rahoveanu M.M., 2013; Greer, 2017), the numerous reforms of the Common Agricultural Policy have modelled and reoriented the European agricultural system, emphasizing its multifunctional aspects, in which the need to ensure food safety and security have become priorities.

Thus, in a functional and highly competitive market economy, the agricultural market develops mechanisms with extremely volatile behaviour, determined by the very nature of agri-food production, which by definition is inflexible in terms of price; the significant and unexpected changes of the production volume impose noteworthy periods and price changes to restore the markets' equilibrium.

Ensuring food production, as a classical function of agriculture, determines its central role in contemporary societies (Andrei, Mieilă and Panait, 2017; Istudor et al., 2014), involving important financial and labour resources. Food production is closely correlated with the availability and quality of natural resources it utilizes and upon which it depends at the same time, generating a determined impact on the quality of the population's health and on the food model it defines. As a consequence, food supply is often much less reactive to the evolution of food prices and to the general market situation, but being strongly dependent on the market of each aliment.

Defining and establishing a sustainable food system that ensures a high level of food safety and food security is a decisive objective, of maximum importance and topicality for all modern economies, including Romania, whose realisation implies a conjugated, multilateral effort from the state and economic agents and especially from the consumers. From this perspective, the achievement of food safety objectives involves the functional integration of 
all components and associated activities, both of food production itself and of its related activities, namely: processing, transport and storage, marketing and final consumption. The lack of population's access to food, but especially its precariousness, can contribute to the increase of social instability and to amplifying the gaps in rural agricultural areas.

Starting from the observation that food security is a decisive component in defining the national agricultural model, Istudor et al. (2014) appreciate that the evolution of the agricultural sector and the agricultural production, in general, must be circumscribed to the requirements imposed by this dimension.

The rise in agricultural commodity prices and agricultural production factors, price volatility, sustainable procurement policies, changes in the agricultural sector as a result of the reforms imposed by the Common Agricultural Policy regarding the direct support mechanism for production (Andrei, Mieilă and Panait, 2017; Malatinec, 2017) determine challenges both in terms of the sustainability of the European food sector and in terms of food security. Sustainable functionality of the food supply chain in the context of food security requires an extensive process of reconnecting agricultural producers with consumers in specific, functional markets, as well as a relocation of agricultural and food production in order to maximize the available agricultural potential.

Transformations of the contemporary agricultural paradigm have imposed food security as one of the key elements of the European agricultural model, alongside food security and rural development. Achieving food security involves reorienting and capitalizing on existing, but little used, components such as: short supply chains, local agricultural systems and alternative food networks.

Considering the above mentioned aspects, the achievement of food safety objectives in the case of Romania is circumscribed to the classical dimensions of this concept. Therefore, the aim of this paper is to analyse the correlation between the dimensions of food safety and security in Romania, using an econometric approach based on nine fundamental variables, in order to highlight these phenomena. The structure of the paper supports this objective and consists of the following sections: the review of the main studies of the literature relevant to the analysed field, which complements the works mentioned in the introductory part of the paper, the presentation of the data series and the preliminary results used in the analysis, the research methodology applied in the processing of data series, the results and discussions on the influence of the variables analysed on food safety and security, as well as conclusions on the subject addressed throughout the paper.

\section{Review of the scientific literature}

The complex food safety issue has imposed a multifaceted approach in the literature, being a subject with profound implications, whether it is analysed at macroeconomic or at company level (Buşe et al., 2007). The notion of food safety implies multiple meanings, often found to be overlapped with food security (Hanning et al., 2012); analysing this notion, Pinstrup-Andersen (2009) highlights the concept's meaning mutations over time.

Food safety is often linked to fundamental problems of the global agri-food system, being itself a global problem. Thus, it is influenced by the change in the agricultural paradigm (Andrei, Mieilă and Panait, 2017; Sima and Gheorghe, 2015), the land grabbing (Ciutacu, Chivu and Andrei, 2017) or the volatility of agri-food prices (Andrei et al., 2016). Scott 
(2003) and Zanin et al. (2017) also found that food security is a critical component in ensuring the sustainable development of contemporary economies, and any problem triggered within a certain state has a contagion effect, propagating in the case of other states as well. The need to ensure food safety standards is important for all products, whether of animal or vegetal origin or industrially processed, regardless of the production process, the distribution chain or their addressability (Post, 2006; Aoki, 2011; Strauss, 2014). King et al. (2017) argue that without achieving the objectives of food safety and security, the objectives of sustainable development cannot be achieved.

Thus, De Boeck et al. (2015) described the development and validation of an instrument for measuring the food safety climate in the company, while an important part of the literature analyses the psychological aspects of food safety, as in Byrd-Bredbenner et al. (2007), da Cunha et al. (2013), Bezerra, Mancuso and Heitz (2014).

Achieving a sustainable food security requires the application of a multi-level global strategy, with a tight connection between all of its components and as Godfray et al. (2010) acknowledge, the solution is not only about maximizing agricultural production but, above all, about its optimization and adaptation to the demands imposed by the environment, social justice and the size of agricultural holdings. In Romania, food safety studies focus on the same approach related to the global dimension issues (Ene, 2009; Bazga, 2012; Neagu, 2015).

\section{Presentation of data series and preliminary results}

In order to accomplish the objectives undertaken in the research, specific data sets, available from the Food and Agriculture Organization of the United Nations website (Food and Agriculture Organization of the United Nations, 2017), were used. Table no. 1, presented below, describes the variables (data series) used for analysis, the availability period, the measuring units for each of the variables, as well as the symbols used for each series in the case of Romania.

Table no. 1: Data series used in research

\begin{tabular}{|l|l|c|}
\hline \multicolumn{1}{|c|}{ Symbol } & \multicolumn{1}{|c|}{ Variable description } & $\begin{array}{c}\text { Data } \\
\text { availability }\end{array}$ \\
\hline AIWS & Share of population with access to compliant water sources (\%) & $1990-2014$ \\
\hline AVFP & Average value of food production (constant 1\$ per person) (3-year average) & $1990-2013$ \\
\hline EM_AG & Emissions (CO 2 equivalent) in agriculture (ths. giga-grams) & $1990-2014$ \\
\hline FA & Food availability - Average protein supply (g/capita/day) (3-year average) & $1990-2011$ \\
\hline FI_MEX & Value of food imports over total goods exports (\%) (3-year average) & $1990-2013$ \\
\hline FPV & Per capita food production variability (1\$ per person constant 2004-2006) & $1990-2013$ \\
\hline FSV & Per capita food supply variability (kcal/capita/day) & $1990-2011$ \\
\hline GDP & Gross Domestic Product per capita, PPP (constant 2011 ths. \$) & $1990-2014$ \\
\hline SH_ECRT & $\begin{array}{l}\text { Share of dietary energy supply derived from cereals, roots and tubers (\%) (3-year } \\
\text { average) }\end{array}$ & $1990-2011$ \\
\hline
\end{tabular}

Source: Food and Agriculture Organization of the United Nations, 2017 
Considering the data presented in table no. 1, one can notice that the availability of food safety data for some variables used in the research is uneven and the common data availability time frame is $1990-2011$.

The main indicators characterising the data series used within the paper, obtained by their statistical processing, in order to outline an overview of the evolution of the variables considered for the analysed period, are presented in table no. 2.

Table no. 2: The main statistical indicators of the data series

\begin{tabular}{|l|c|c|c|c|c|c|c|c|c|}
\hline & AIWS & AVFP & EM_AG & FA & FI_MEX & FPV & FSV & GDP & SH_CRT \\
\hline Mean & 86.045 & 356.6 & 16.715 & 99.6 & 8.1 & 25.175 & 58.55 & 123.92 & 47.2 \\
\hline Median & 85.9 & 355 & 15.587 & 98 & 7 & 25.7 & 43.5 & 108.38 & 47 \\
\hline Maximum & 96.9 & 394 & 23.662 & 110 & 16 & 41.6 & 119 & 185.6 & 51 \\
\hline Minimum & 75.4 & 330 & 14.306 & 88 & 6 & 7.3 & 22 & 90.4 & 43 \\
\hline Std. Dev. & 6.694 & 19.736 & 2.455 & 7.789 & 2.972 & 9.469 & 32.965 & 31.5 & 2.462 \\
\hline Skewness & 0.040 & 0.454 & 1.569 & -0.060 & 1.653 & 0.041 & 0.875 & 0.748 & -0.171 \\
\hline Kurtosis & 1.789 & 2.203 & 4.658 & 1.491 & 4.657 & 2.479 & 2.197 & 2.053 & 1.691 \\
\hline Jarque- & 1.227 & 1.217 & 10.498 & 1.909 & 11.401 & 0.232 & 3.090 & 2.611 & 1.525 \\
\hline Bera & 0.542 & 0.544 & 0.005 & 0.385 & 0.003 & 0.890 & 0.213 & 0.271 & 0.466 \\
\hline Probability & 1720.9 & 7132 & 334.2942 & 1992 & 162 & 503.5 & 1171 & 2478.5 & 944 \\
\hline Sum & 851.4 & 7400.8 & 114.5 & 1152.8 & 167.8 & 1703.7 & 20647.0 & 18862.5 & 115.2 \\
\hline S.Sq.Dev. & 8520 & 20 & 20 & 20 & 20 & 20 & 20 & 20 \\
\hline Obs. & 20 & 20 & 20 & & & & & \\
\hline
\end{tabular}

Figure no. 1 contains the graphical representation of the data series for the analysed time interval as follows: the abscissa records the period of data availability, respectively the interval 1990-2014, while on the order, the units of measurement are those related to each variable, as presented in table no. 2 .

From the analysis of the data series presented in figure no. 1, we can notice some specific evolutions of each component used in this research, as follows:

- the share of the population at national level benefiting from access to compliant water sources (AIWS) has been steadily rising from 75.4\% in 1990 to 100\% from 2013 to the end of the period under review;

- average value of food production (AVFP) has experienced a "saw teeth" evolution amid a general upward trend from a minimum of 330 between 1990 and 1992, a local top of 362 between 1995 and 1997, and a return to the initial situation in the period between 19982000 , in the course of the manifestation of the effects of the structural crisis of the national economy overlapped with the global depression induced by the Asian financial crisis (Granger, Huangb and Yang, 2000; Muchhala, 2007; Noland et al., 1998; Pempel, 1999; Pettis, 2001; Riès, 2000), followed by a rally of up to 397 in 2004-2006. Due to the dependence on climatic conditions, the moving averages of the 2005-2009 period ranged from 357-360, followed by a new expansion period, with values in the range of 377-385, for the 2008-2013 timeframe; 
AIWS

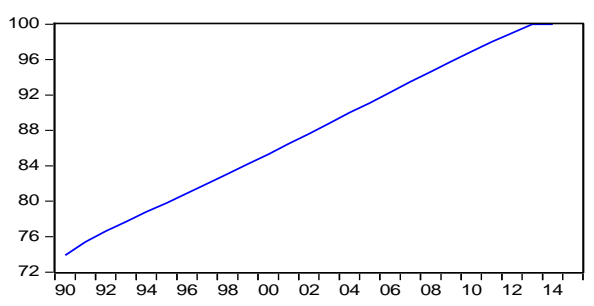

EM_AG

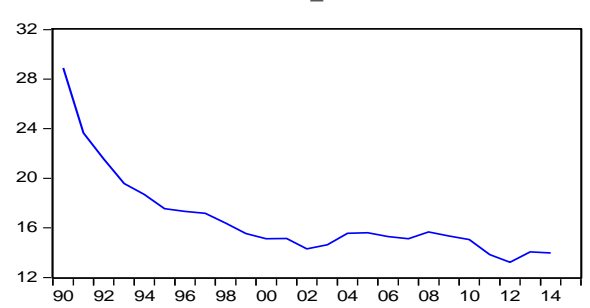

FI_MEX

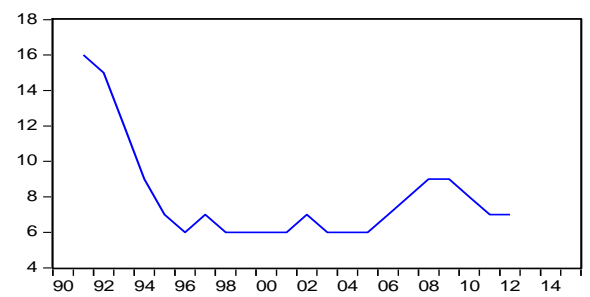

FSV

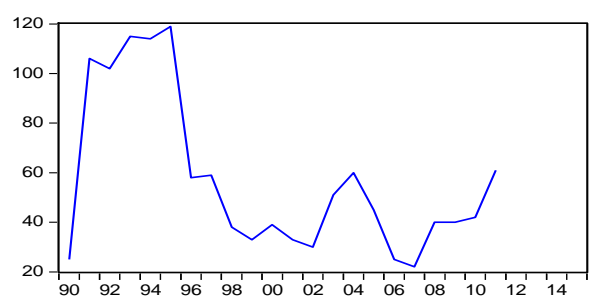

SH_CRT

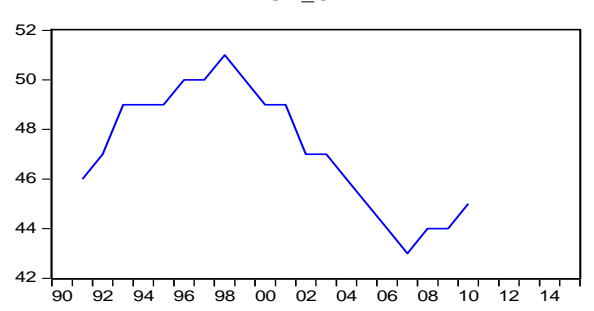

AVFP

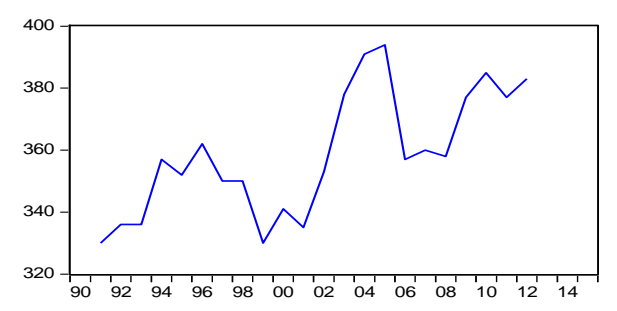

FA

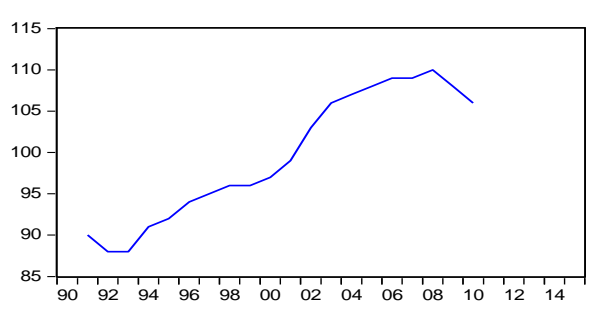

FPV

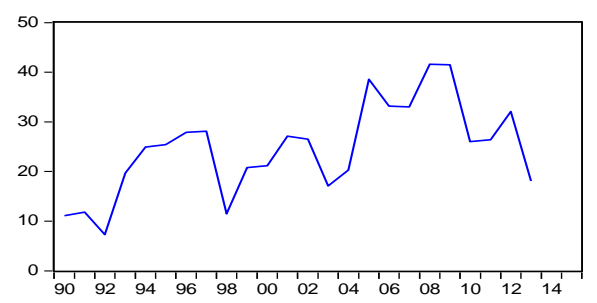

GDP

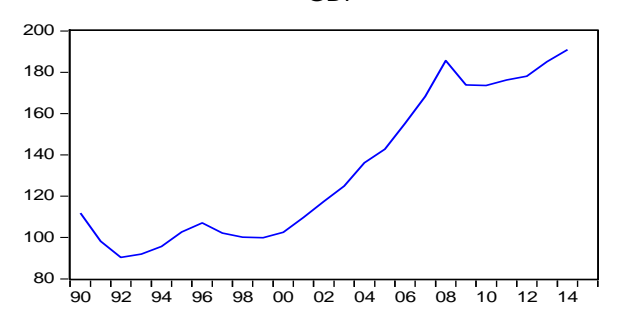

Figure no. 1: Evolution of the variables considered in research, 1990-2014 
- the continuous reduction of carbon emissions from agricultural activities (EM_AG), from a peak of about 29,000 giga-grams of $\mathrm{CO}_{2}$ equivalent in 1990 to about 17500 gigagrams of $\mathrm{CO}_{2}$ equivalent in 1995. The downward trend of the indicator continued after that, but with much reduced rates and certain local maxima of low amplitude, up to about 14,000 giga-grams of $\mathrm{CO}_{2}$ equivalent in 2013;

- average protein supply (food availability - FA) improved continuously, from $90 \mathrm{~g} / \mathrm{day}$ per capita, after a slight reduction to 88 g/day per capita in 1991-1994, on the basis of the process of transition to a market economy in full swing in Romania during that period, reached 91 g/day per capita within the timeframe 1992-1995 and has continuously improved to a peak of 110 in 2007-2009, followed by a gradual reduction to $106 \mathrm{~g} / \mathrm{day}$ per capita as the average of 2009-2011 interval;

- the value of food imports over total merchandise exports (FI_MEX) recorded a steady downward trend from an average of 16\% between 1990-1992 to 6\% between 1997 and 2002, followed by increases and decreases of low amplitude to $9 \%$ in the 2007-2010 period. These developments are the result of the combined action of various factors, partially overlapping at certain intervals: increased agricultural production, including the subsistence one, which has allowed the reduction of market demand; a similar effect is the decline in solvable demand in times of economic crisis; on the other hand, the increase in export value has led to a decrease in imports relative to the former; not lastly, revenue growth has led to a diversification of market requirements for high-quality food goods, which may, to some extent, justify certain increases in the indicator. All these developments describe global improvement in access to food resources for the population;

- food production variability (FPV) has seen a "saw teeth" evolution amid a general upward trend, from a minimum value of 7.3 in 1992 to a peak of 41.6 and 41.5 in 2008 and 2009, a downward trend to around 26 in 2010-2011, a rebound to 32 in 2012 and a deterioration to 18 in 2013;

- food supply variability (FSV) has evolved steeply, from a minimum of $25 \mathrm{kcal} / \mathrm{day}$ per capita to a maximum of $119 \mathrm{kcal} /$ day in 1995, followed by an equally steep decline to a value of $33 \mathrm{kcal}$ per capita in 1999 and 2001, local maxima of $60 \mathrm{kcal} /$ day per capita in 2004 and $61 \mathrm{kcal} /$ day per capita in 2011, but also a minimum set value of $22 \mathrm{kcal} /$ day per capita in 2007. These data describe a "saw teeth" development with stationary characteristics;

- Gross Domestic Product (GDP) has steadily ascended, especially after 2000 , interrupted by the 2009 financial crisis, but resuming the upward trend since 2010, with slightly mitigated rhythms;

- the share of dietary energy supply derived from cereals, roots and tubers (SH_ECRT) is an important indicator of the quality of the food consumed. This indicator has risen steadily from $46 \%$ between $1990-1992$ to $51 \%$ between 1997 and 1999, followed by deterioration down to the $43 \%$ minimum in 2006-2008 and the upward trend, reaching $45 \%$ at the end of the interval of analysis. 


\section{Research methodology}

Research conducted by Byrd-Bredbenner et al. (2007), Godfray et al. (2010), Hanning et al. (2012) and Post (2006) in the field of food safety revealed varied results, depending on the functional form considered, the econometric approach adopted, the time interval, the area under analysis or the variables taken into account. The use of econometric instruments to carry out the current research implies, in this case also, highlighting the non-stationary character of the data series, by using specific tests, either at individual level, for each data series (Augmented Dickey-Fuller - ADF and Phillips-Perron - PP tests), either a form of the IPS test (Im, Pesaran and Shin, 2003) adapted to the specificity of the chronological series, available in the EViews program package (Quantitative Micro Software, 2010). In view of the particular complexity of the concept and of the dimension of food safety, which requires the use of an analysis model for a large number of variables, in the specialised literature, when analysing the existence and direction of the correlations present between sets of non-stationary variables, the co-integrative approach is employed, in order to highlight the long-term equilibrium relationship between the variables under consideration (Choi, 2001; Engle and Granger, 1987; Hansen, 1992).

Starting from the general observation that the phenomenon of endogeneity is usually manifested between chronological series, one can assume the possibility that there is a causal relationship between them, as defined by Granger (1988). Considering the existence of a set of endogenous and co-integrated variables, the appropriate econometric approach is centred on obtaining accurate and unbiased estimates for which Granger causality tests are used. These represent an appropriate solution for properly applying the analysis methods specific for co-integrated series and observing the Error Correction Mechanism (ECM), as well as examining short and long-term relationships between the analysed variables as found in Granger, Huangb and Yang (2000); Engle and Granger (1987). In addition, as stated by Al-Sadoon (2009), the concept of Granger non-causality also incorporates certain related concepts such as co-integration, stability and controllability. To the authors' knowledge, the present paper is the first attempt to use Granger causality tests and the subsequent techniques in studying the causal relationship between food safety and security and the exogenous variables considered on Romania's example.

In a broad sense, testing the causal relationship between food safety and the exogenous variables subject to analysis is carried out in three stages. The first one involves testing the order of integration of each of the variables. Further, co-integration tests are used to examine the long-term relationships between the variables. As a result, after identifying a set of first order integrated series, the next step is to perform co-integration analysis as a technique to investigate the existence of a long-term relationship between the set of embedded variables in question (Abdullah and Morley, 2014; Phillips and Hansen, 1990).

When a co-integration situation is highlighted, differentiation issues (represented by the loss of information about long-term relationships between variables) can be avoided by using an Autoregressive Vector (VAR) model in order to verify the existence of a stationary linear combination among non-stationary variables, involving a long-term equilibrium relationship between these variables. The third step entails the use of dynamic causality tests with the aim of assessing the short-term and long-term causality of the analysed variables (Constantini and Martini, 2010; Granger, Huangb and Yang, 2000; Judson and Owen, 1999). 
Considering the standard triangular representation of the regression specification and assuming the existence of a single co-integration vector (Hansen, 1992; Phillips and Hansen, 1990), for a vectorial process $\left(y_{t}, X_{t}^{\prime}\right)$ related to a chronological series of $n+1$ dimension, the co-integration equation is given by:

$$
y_{t}=X_{t}^{\prime} \beta^{\prime}+D_{1 t}^{\prime} \gamma_{1}+u_{1 t}
$$

in which $D_{t}=\left(D_{1 t}^{\prime}, D_{2 t}^{\prime}\right)$ are the regressors of the deterministic trends, and the $n$ dimensional stochastic regressors $X_{t}$ are determined by the system of equations:

$$
\begin{aligned}
& X_{t}=\Gamma_{21}^{\prime} D_{1 t}+\Gamma_{22}^{\prime} D_{2 t}+\varepsilon_{2 t} \\
& \Delta \varepsilon_{2 t}=u_{2 t}
\end{aligned}
$$

The dimensional vector $r_{1}$ related to the exogenous variables $D_{1 t}$ enters both the cointegration equation and the regressors equation, while the dimension vector $r_{2}$ related to the deterministic trends $D_{2 t}$ appears in the equations of the regressors, but is excluded from the co-integration equation. If a regressor, other than the trend ones, is present, it is presumed to belong to $D_{1 t}$, which implies that it is not an element of $D_{2 t}$.

Following the approach described by Hansen (1992), as hypothesis, innovations are strictly stationary and ergodic with a zero mean. On this basis, the following are defined: the contemporary covariance matrix $\Sigma$, the long-term unilateral covariance matrix $\Lambda$ and the long-term non-singular covariance matrix $\Omega$, as follows:

$$
\begin{aligned}
& \Sigma=E\left(u_{t} u_{t}^{\prime}\right)=\left[\begin{array}{ll}
\sigma_{11} & \sigma_{12} \\
\sigma_{21} & \sigma_{22}
\end{array}\right] \\
& \Lambda=\sum_{j=0}\left(u_{t} u_{t-j}^{\prime}\right)=\left[\begin{array}{ll}
\lambda_{11} & \lambda_{12} \\
\lambda_{21} & \lambda_{22}
\end{array}\right] \\
& \Omega=\sum_{j=0}\left(u_{t} u_{t-j}^{\prime}\right)=\left[\begin{array}{ll}
\omega_{11} & \omega_{12} \\
\omega_{21} & \omega_{22}
\end{array}\right]=\Lambda+\Lambda^{\prime}-\Sigma
\end{aligned}
$$

Thus, the hypotheses imply that the elements $y_{t}$ and $X_{t}$ are $I(1)$ and also co-integrated, but exclude both co-integration between $X_{t}$ elements and multi-co-integration.

In order to apply the methodology described above, usually the first step is to test the existence of a unit root within the data series. The most widely used test in this regard is the one proposed by Im, Pesaran and Shin (IPS) (2003), which is also used in the present paper. The autoregressive model employed in this test is of the form:

$$
\Delta y_{i t}=\rho y_{i, t-1}+\sum_{L=1}^{p i} \theta_{i L} \Delta y_{i, t-L}+\delta X_{i t}^{\prime}+\varepsilon_{i t}
$$


where the notation $i=\overline{1, N}$ was used for the series of data previously presented (AIWS, $\left.A V F P, E M \_A G, F A, F I \_M E X, F P V, F S V, G D P, S H \_E C R T\right)$ and observed over the time interval $t=\overline{1, T} ; p_{i}$ is the lag order of each series, which can be variable and is determined on the basis of the $t$ statistics of $\hat{\theta}_{i L}$ (under the null hypothesis $\left(\hat{\theta}_{i L}=0\right)$, the $t$ statistics follows a normal distribution, whether $\rho_{i}=0$ or $\left.\rho_{i}<0\right) ; X_{i t}^{\prime}$ are the exogenous variables of the model, the autoregressive coefficients being noted with $\rho_{i}$, while $\varepsilon_{i t}$ is a stationary process. If $\rho_{i}<1$, then $y_{i}$ is considered to be weakly stationary in trend; if $\rho_{i}=1, y_{i}$ is not stationary and the series contains a unit root.

Following the general approach of the Granger causality tests, testing the existence of a cointegration process makes sense only in the case of the series describing an integrated process of a similar order, generally of the first order, $I(1)$.

According to Granger's (1988) demonstration, the existence of a co-integration ratio in a pair of series $I(1)$ implies the existence of a causal relationship in at least one direction. Starting from this hypothesis, the presence of co-integration involves the possibility of forming a Vector Error Correction Model (VECM), whose Error Correction Term (ECT) has a significant effect on the dependent variable.

As used in previous studies (Arellano and Bond, 1991; Pedroni, 2004; Andrei, Mieilă and Panait, 2017), the co-integration relationships incorporated in the specification of the Vector Error Correction Model (VECM) have the effect of restricting the long-term behaviour of endogenous variables in the direction of convergence towards the cointegration relations, while highlighting the short-term adjustment dynamics. As argued in the work of Arellano and Bond (1991), the Generalized Moments Method (GMM) can be utilized with significant results when estimating autoregressive vectors, using the lag operators of the endogenous variables as instruments for the calculation of unbiased and consistent estimators.

Also, as highlighted in the specialised literature (Arellano and Bond, 1991; Arellano and Bover, 1995; Pedroni, 2004; Andrei, Mieilă and Panait, 2017), the model can be specified by considering the relations:

$$
\begin{aligned}
& \Delta F A_{t}=\alpha^{f a}+\beta^{f a} E C T_{t-1}^{f a}+\sum_{j=1}^{m} \delta_{j}^{f a} \Delta F A_{t-j}+\sum_{s=1}^{q} \gamma_{1, s}^{f a} \Delta F S V_{t-s}+\ldots+\sum_{s=1}^{v} \gamma_{4, s}^{f a} \Delta F P V_{t-v}+u_{t} \\
& \Delta F P V_{t}=\alpha^{f p v}+\beta^{f p v} E C T_{t-1}^{f v}+\sum_{j=1}^{m} \delta_{j}^{f p v} \Delta F A_{t-j}+\sum_{s=1}^{q} \gamma_{1, s}^{f p v} \Delta F S V_{t-s} \ldots+\sum_{s=1}^{v} \gamma_{4, s}^{f p v} \Delta F P V_{t-v}+w_{t}
\end{aligned}
$$

in which $E C T_{t-1}^{f a, . ., s_{-} e c r t}$ represent the residual values derived from the long-term cointegration relation, $\delta_{i, t-1}^{f a, \ldots, f p v}, \quad \gamma_{1, . ., 4}^{f a, \ldots, f p v}$ are the short-term adjustment coefficients, $\gamma_{1, \ldots, 4}^{f a, \ldots, f p v}$ are the lag coefficients, while $u_{t}$ and $w_{t}$ are the terms of error, which are supposed to be uncorrelated and of zero mean.

This research is based on the existing approaches available in the international literature such as the one of Arellano \& Bover (1995) for assessing the significance of beta 
coefficients (for the Error Correction Term - ECT), Granger, Huangb and Yang (2000); Abdullah and Morley (2014) for the conjugate meaning (F statistics) of the lag explanatory variables, while also revealing the advantages noted by Bond (2002).

\section{Results and discussions}

The results of the IPS unit root test are shown in table no. 3. They show that data series related to the variables emissions in agriculture and the value of food imports over total exports of goods are stationary; all other series, with the exception of food availability (average protein intake), are non-stationary and contain a unit root, which means that they are suitable for testing for co-integration and modelling according to VEC techniques.

Table no. 3: Results of the IPS unit root test

\begin{tabular}{|l|c|c|c|c|}
\hline \multirow{2}{*}{ Variable } & \multicolumn{2}{|c|}{ Simultaneous } & \multicolumn{2}{c|}{ Differential } \\
\cline { 2 - 5 } & Fixed effects & Fixed effects and trend & Fixed effects & Fixed effects and trend \\
\hline AIWS & -1.3935 & 0.2788 & 1.1063 & 2.1904 \\
\hline AVFP & -1.839 & $-4.5319^{*}$ & $-3.8166^{* *}$ & $-3.6446^{* *}$ \\
\hline EM_AG & $-9.6248^{* * *}$ & $-8.2887^{* * *}$ & $-5.994^{* * *}$ & $-5.6221^{* * *}$ \\
\hline FA & -2.1542 & -0.7443 & -2.3864 & -2.677 \\
\hline FI_MEX & $-4.02^{* * *}$ & -2.9958 & -2.2404 & -2.6493 \\
\hline FPV & -2.6147 & -2.6921 & $-4.8809^{* * *}$ & $-5.3114^{* * *}$ \\
\hline FSV & -1.9949 & -3.2365 & $-6.1887^{* * *}$ & $-5.9416^{* * *}$ \\
\hline GDP & 0.7027 & -2.2098 & $-3.6349^{* *}$ & $-3.5148^{* *}$ \\
\hline SH_ECRT & -2.2378 & -2.6548 & $-3.2236^{* *}$ & -0.0344 \\
\hline IPS W-stat & $-4.137^{* * *}$ & $-2.906^{* * *}$ & $-6.252^{* * *}$ & $-2.947^{* * *}$ \\
\hline
\end{tabular}

Note: The lag length determined using the Schwartz information criterion.

Differentiated refers to series obtained as a result of first-order differences.

$* * *, * *, *$ Indicates the significance at 1,5 and $10 \%$ (unilateral test).

The significant results of the Granger causality tests for the pairs of series under analysis are shown in table no. 4. Following the approach presented by Granger, Huangb and Yang (2000), testing of the co-integrative process runs two-way, each of the variables acting as a dependent variable.

Table no. 4: Significant results of Granger causality tests

\begin{tabular}{|c|c|c|c|c|c|c|c|c|c|}
\hline Variables & AIWS & AVFP & EM_AG & FA & FI_MEX & FPV & FSV & GDP & SH_ECRT \\
\hline AIWS & - & & & & & & & $3.17^{*}$ & $3.72^{*}$ \\
\hline AVFP & & - & & & & & & & $4.11^{* *}$ \\
\hline EM_AG & & & - & & & & & & \\
\hline FA & & & & - & & & & & $5.90^{* *}$ \\
\hline FI_MEX & $2.95^{*}$ & & & & - & & $10.52^{* * *}$ & & $4.21^{* *}$ \\
\hline FPV & & & & & & - & & & \\
\hline FSV & & $3.26^{*}$ & & & & & - & & \\
\hline GDP & & & & $3.03^{*}$ & & $9.24^{* * *}$ & & - & $2.77^{*}$ \\
\hline SH_ECRT & & & & & $3.87^{* *}$ & $3.14^{*}$ & & $8.04^{* * *}$ & - \\
\hline
\end{tabular}

Note: In the first column, the explanatory variable in the co-integration relation; table head dependent variable.

$* * *, * *, *$ Indicates the rejection of the null hypothesis of absence of co-integration for a significance threshold of 1,5 and $10 \%$, respectively. 
The results of the co-integration tests suggest that the share of dietary energy supply derived from cereals, roots and tubers, which is an important indicator of the quality of the food ration and which can be considered a significant measure of food safety, is under causal influence (in the Granger sense) of all other variables considered in the model, except for the carbon emissions in agriculture, the food production variability and the food supply variability, respectively. Instead, this variable ( $\left.S H \_E C R T\right)$ exerts a significant influence on the value of food imports over total goods exports, the food production variability and Gross Domestic Product. The latter exerts a significant influence on the food supply availability and variability. The presented results suggest that the variables average value of food production, food availability, value of food imports over total goods exports, food production variability, food supply variability, Gross Domestic Product, and the share of dietary energy supply derived from cereals, roots and tubers may be in a cointegration relation. Subsequently, Granger's co-integration test was used to test this relation. The statistic value $z$ represents the normalized autocorrelation coefficient for the residual values obtained by using each series within the group as a variable in the cointegration regression; the results obtained are presented in table no. 5 .

Table no. 5: Results of the Granger co-integration test

\begin{tabular}{|c|c|}
\hline Variable & $\begin{array}{c}\text { Value of statistic value } z \\
\text { of the Granger co-integration test }\end{array}$ \\
\hline AIWS & $78.15^{* * *}$ \\
\hline AVFP & $-25.14^{*}$ \\
\hline EM_AG & -19.25 \\
\hline FA & -21.45 \\
\hline FI_MEX & $-64.66^{* * *}$ \\
\hline FPV & $53.93^{* * *}$ \\
\hline FSV & -24.51 \\
\hline GDP & -16.00 \\
\hline SH_ECRT & $-42.36^{* * *}$ \\
\hline
\end{tabular}

Note: The lag length determined based on the Schwarz information criterion (maxlag $=3$ ) All test equations include the individual constant ("fixed effects")

$* * *, * *, *$ Indicates the rejection of the null hypothesis of absence of co-integration for significance thresholds of 1,5 and $10 \%$, respectively.

By analysing table no. 5, mixed results can be observed, but in most cases the null hypothesis of lack of co-integration is rejected. Also, taking into account the results of the Granger causality tests on the pairs of series, the inclusion of ECT in the VEC model can be considered as reliable. Among the presented variables, the following ones can be considered as relevant for food safety: average value of food production, food availability, food production variability and food supply variability, whilst considering the other variables as exogenous within the system.

Table no. 6 presents the results of the VEC model estimate and default term based on the Arellano-Bover approach. 
Table no. 6: Estimating the Error Correction Term in the Vector Error Correction model

\begin{tabular}{|c|c|c|c|c|c|c|}
\hline \multirow{2}{*}{ Variable } & \multirow{2}{*}{$\begin{array}{c}\text { ECT coefficient } \\
(\boldsymbol{t} \text {-stat })\end{array}$} & \multirow{2}{*}{$\begin{array}{c}\text { Adjustment } \\
\text { speed } \\
(\boldsymbol{t} \text {-stat })\end{array}$} & \multicolumn{4}{|c|}{$\begin{array}{c}\text { Lag coefficient } \\
(\boldsymbol{t} \text {-stat })\end{array}$} \\
\cline { 4 - 7 } & & $-0.152(-0.59)$ & $-0.06(-0.20)$ & $-0.03(-1.06)$ & $-0.22(-1.57)$ & $0.18(0.64)$ \\
\hline AVFP & 1.00 & AVFP & FA & FPV & FSV \\
\hline FA & $-13.84(-10.75)^{* * * *}$ & $0.034(1.57)$ & $1.998(0.45)$ & $0.86(2.34)$ & $3.66(1.87)$ & $8.42(2.17)$ \\
\hline FPV & $-4.47(-16.03)^{* * *}$ & $0.353(3.07)$ & $-0.37(0.50)$ & $0.12(1.94)$ & $0.43(1.27)$ & $0.56(0.83)$ \\
\hline FSV & $-0.81(-7.19)^{* * *}$ & $0.397(1.74)$ & $0.502(2.11)$ & $0.01(0.71)$ & $0.06(0.62)$ & $-0.07(-0.33)$ \\
\hline AIWS & & & $-1.46(-0.51)$ & $0.21(0.88)$ & $3.54(2.80)$ & $3.94(1.57)$ \\
\hline EM_AG & & & $-5.78(-0.84)$ & $-0.14(-0.25)$ & $6.12(2.02)$ & $-7.95(-1.31)$ \\
\hline FI_MEX & & & $5.94(1.23)$ & $0.09(0.23)$ & $-1.64(-0.77)$ & $11.99(2.82)$ \\
\hline GDP & & & $-0.38(-0.40)$ & $0.07(0.91)$ & $0.58(1.37)$ & $0.58(0.69)$ \\
\hline SH_ECRT & & & $1.01(0.22)$ & $-1.12(-0.57)$ & $-1.12(-0.56)$ & $1.69(0.43)$ \\
\hline
\end{tabular}

Note: Length of the lag: 1,1

$* * *, * *$ indicates the meaning of the estimator for significance thresholds of 1 and $5 \%$, respectively.

Figure no. 2 graphically represents the responses to the impulses (innovations) of the endogenous variables, according to the methodology presented above, in which the impulse is given by the change with the value of the standard deviation in the generating variable.

Response of AVFP to Nonfactorized One S.D. Innovations

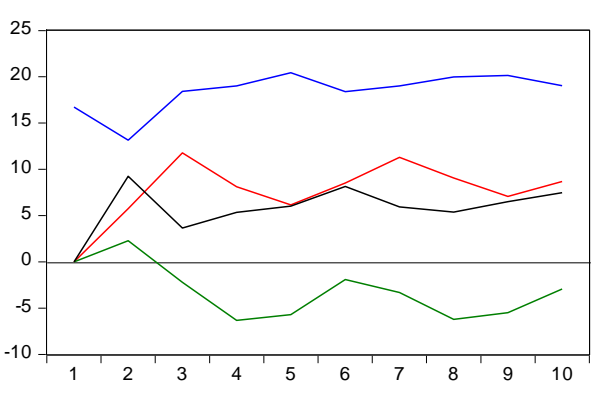

- AVFP - FA - FPV - FSV

Response of FPV to Nonfactorized One S.D. Innovations

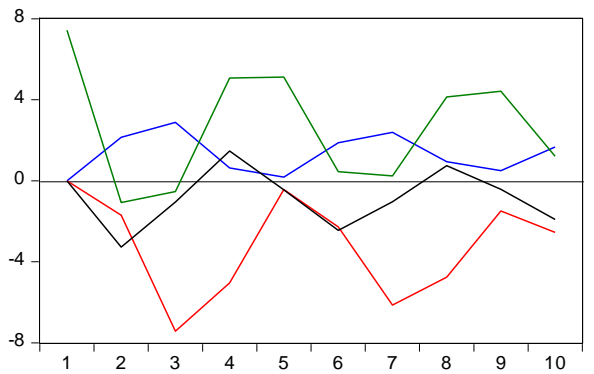

- AVFP FA FPV - FSV
Response of FA to Nonfactorized One S.D. Innovations

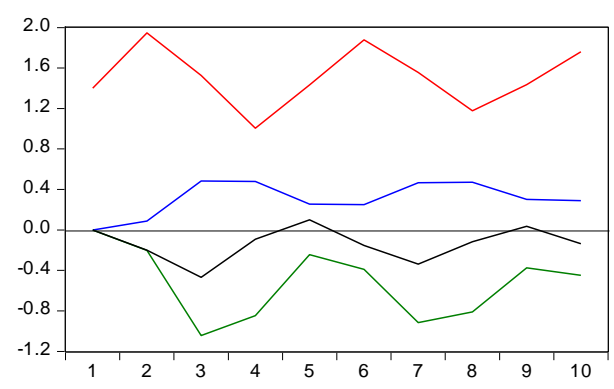

- AVFP - FA FPV - FSV Response of FSV to Nonfactorized One S.D. Innovations

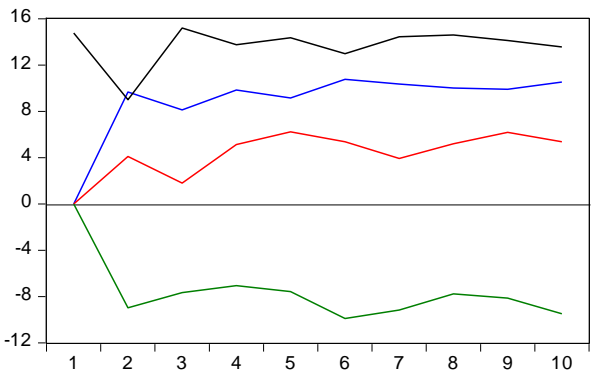

- AVFP - FA FPV - FSV

Figure no. 2: Responses to innovations of endogenous variables - the impulse value is equal to the standard deviation of the generating variable 
The significant results of the estimated Error Correction Terms - ECT highlight the tendency of over-targeting the equilibrium on the long-term within the co-integration equation in the case of food availability and food production variability; instead, the value of the food supply variability coefficient shows that a large part of the imbalance is discarded through the activity of economic agents - however, as a long-term trend. Concerning the short-term adjustment speed as well as the influence of the exogenous variables, an important explanation of the fact that the results are not statistically significant is given by the small size of the data series. On the other hand, these results are part of the broader framework of atypical developments determined by the reorganisation of the economic activity in our country during the analysed period of time.

\section{Conclusions}

Food safety is a matter of high importance both in the research conducted within the specialised literature and from the perspective of the economic realities, in the context of ensuring the convergence with the requirements of the European agricultural model and the transformations imposed by the extensive processes of integration and globalization of markets and agricultural production. The crucial element in achieving food safety objectives is sustainable agricultural production at the level of local communities, the only ones able to use and adequately dimension agricultural resources. In this respect, it is necessary to systematically plan the security of supply with agri-food products, ensuring the viability of the components of the entire agricultural sector, and above all, the sustainability of agricultural production, in order to eliminate potential exposures to risk and uncertainty.

For the particular case of Romania, given the significant results of the estimated ECT obtained from the present analysis, one can easily distinguish a decisive tendency to overtarget the long-term equilibrium, evidenced by the form of the co-integration equation in the case of two of the variables used - food availability and food production variability, respectively. At the same time, the value of the food supply variability coefficient indicates the effect and implications of the economic activity specific to the agri-food economic agents to compensate on the long term for the characteristic imbalances of the agricultural market and to guarantee both food safety and food security.

The present paper represents an endeavour to use Granger causality tests and co-integration techniques in studying the relationship between the variables considered as defining for food safety and security in Romania's case. As a result, there are certain limits to the interpretation of the results, limits determined by the restricted size of the national data sets. From a strictly econometric point of view, potential future research could take into account, provided that information is available, longer data series, as well as other states; however, for the specific case of Romania we considered that by such an extension of the research, the practical relevance of the results would have been significantly diminished.

From the analysis of the evolution of the variables considered in this research, it can be noticed that although in Romania food safety is achieved, there are some components that need to be improved and refined, thus imposing better food traceability, a superior 
valorisation of agricultural resources and also strengthening the specific components of the local agricultural systems.

\section{References}

Abdullah, S. and Morley, B., 2014. Environmental taxes and economic growth: Evidence from panel causality tests. Energy Economics, 42, pp.27-33.

Al-Sadoon, M.M., 2009. Causality Along Subspaces: Theory. Cambridge Working Papers in Economics. Cambridge.

Andrei, J.V. and Darvasi, D., 2012. Perspectives and Challenges in financing the new Common Agricultural Policy: a new paradigm. Journal of Food, Agriculture and Environment, 10(1), pp.1018-1022.

Andrei, J.V., Ion, A.R., Popescu, G.H., Nica, E. and Zaharia, M., 2016. Implications of agricultural bioenergy crop production and prices in changing the land use paradigmThe case of Romania. Land Use Policy, 50, pp.399-407.

Andrei, J.V., Mieilă, M. and Panait, M., 2017. Transformations of the Romanian agricultural paradigm under domestic economic policy reforms: An analysis during 1960-2011. Land Use Policy, 67, pp.288-297.

Aoki, K., 2011. Food Forethought: Intergenerational Equity and Global Food Supply Past, Present, and Future. Wisconsin Law Review, 2011(2), pp.399-478.

Arellano, M. and Bond, S., 1991. Some Tests of Specification for Panel Data: Monte Carlo Evidence and an Application to Employment Equations. The Review of Economic Studies, 58(2), pp.277-297.

Arellano, M. and Bover, O., 1995. Another look at the instrumental variable estimation of error-components models. Journal of Econometrics, 68(1), pp.29-51.

Bazga, B., 2012. Prospects for Food Security in Romania. Procedia Economics and Finance, 3, pp.1262-1267.

Bezerra, A.C.D., Mancuso, A.M.C. and Heitz, S.J.J., 2014. Alimento de rua na agenda nacional de segurança alimentar e nutricional: um ensaio para a qualificação sanitária no Brasil. Ciência \& Saúde Coletiva, 19(5), pp.1489-1494.

Bond, S., 2002. Dynamic Panel Data Models: A Guide to Micro Data Methods and Practice. [online] Available at: <http://www.cemmap.ac.uk/wps/cwp0209.pdf> [Accessed 25 May 2017].

Buşe, L., Siminică, M., Cîrciumaru, D. and Marcu, N., 2007. Analiza economico-financiară a firmei. Craiova: Editura Sitech.

Byrd-Bredbenner, C., Maurer, J., Wheatley, V., Schaffner, D., Bruhn, C. and Blalock, L., 2007. Food safety self-reported behaviors and cognitions of young adults: results of a national study. Journal of food protection, 70(8), pp.1917-1926.

Choi, I., 2001. Unit root tests for panel data. Journal of international money and finance, 20(2), pp.249-272.

Ciutacu, C., Chivu, L. and Andrei, J.V., 2017. Land grabbing: A review of extent and possible consequences in Romania. Land Use Policy, 62, pp.143-150.

Constantini, V. and Martini, C., 2010. The causality between energy consumption and economic growth: A multi-sectoral analysis using non-stationary cointegrated panel 
data. Energy Economics, 32(3), pp.591-603.

Da Cunha, D.T., Fiorotti, R.M., Baldasso, J.G., de Sousa, M., Fontanezi, N.M., Caivano, S., Stedefeldt, E., de Rosso, V.V. and Camargo, M.C.R., 2013. Improvement of food safety in school meal service during a long-term intervention period: a strategy based on the knowledge, attitude and practice triad. Food Control, 34(2), pp.662-667.

De Boeck, E., Jacxsens, L., Bollaerts, M. and Vlerick, P., 2015. Food safety climate in food processing organizations: Development and validation of a self-assessment tool. Trends in Food Science \& Technology, 46(2), pp.242-251.

Ene, C., 2009. Securitatea alimentară-coordonate şi implicaţii. Ploiești: Editura Universităţii Petrol-Gaze din Ploieşti.

Engle, R.F. and Granger, C.W.J., 1987. Co-Integration and Error Correction: Representation, Estimation, and Testing. Econometrica, 55(2), pp.251-276.

Food and Agriculture Organization of the United Nations, 2017. FAOSTAT Suite of Food Security Indicators. [online] Available at: <http://www.fao.org/faostat/en/\#data/FS> [Accessed 9 May 2017].

Godfray, H.C.J., Beddington, J.R., Crute, I.R., Haddad, L., Lawrence, D., Muir, J.F., Pretty, J., Robinson, S., Thomas, S.M. and Toulmin, C., 2010. Food Security: The Challenge of Feeding 9 Billion People. Science, 327(5967), pp.812-818.

Granger, C.W.J., 1988. Some recent development in a concept of causality. Journal of Econometrics, 39(1-2), pp.199-211.

Granger, C.W.J., Huangb, B.-N. and Yang, C.-W., 2000. A bivariate causality between stock prices and exchange rates: evidence from recent Asianflu. The Quarterly Review of Economics and Finance, 40(3), pp.337-354.

Greer, A., 2017. Post-exceptional politics in agriculture: an examination of the 2013 CAP reform. Journal of European Public Policy, 24(11), pp.1585-1603.

Hanning, I.B., O’Bryan, C.A., Crandall, P.G. and Ricke, S.C., 2012. Food Safety and Food Security. Nature Education Knowledge, 3(10), p.9.

Hansen, B.E., 1992. Tests for Parameter Instability in Regressions with 1(1) Processes. Journal of Business \& Economic Statistics, 10(3), pp.321-335.

Im, K.S., Pesaran, M.H. and Shin, Y., 2003. Testing for unit roots in heterogeneous panels. Journal of Econometrics, 115(1), pp.53-74.

Istudor, N., Ion, R., Sponte, M. and Petrescu, I., 2014. Food Security in Romania-A Modern Approach for Developing Sustainable Agriculture. Sustainability, 6(12), pp.8796-8807.

Judson, R.A. and Owen, A., 1999. Estimating dynamic panel data models: a guide for macroeconomists. Economics Letters, 65(1), pp.9-15.

King, T., Cole, M., Farber, J.M., Eisenbrand, G., Zabaras, D., Fox, E.M. and Hill, J.P., 2017. Food safety for food security: Relationship between global megatrends and developments in food safety. Trends in Food Science \& Technology, 68, pp.160-175.

Malatinec, T., 2017. Legislative framework of green public procurement and Europeanisation of the Slovak practice. Juridical Tribune, 7(Special Issue), pp.95-107.

Muchhala, B. ed., 2007. Ten Years After: Revisiting the Asian Financial Crisis. 
Washington, D.C.: Woodrow Wilson International Center for Scholars.

Neagu, I.-R., 2015. Securitatea versus siguranța alimentară. Revista de investigare a criminalității, 1, p.171.

Noland, M., Liu, L.-G., Robinson, S. and Wang, Z., 1998. Global economic effects of the Asian currency devaluations. Policy Ana (ed.). Washington, D.C.: Institute for International Economics.

Pedroni, P., 2004. Panel cointegration, asymptotic and finite sample properties of pooled time series tests with an application to the PPP hypothesis. Econometric Theory, 20, pp.597-625.

Pempel, T.J. ed., 1999. The Politics of the Asian Economic Crisis. Ithaca: Cornell University Press.

Pettis, M., 2001. The Volatility Machine: Emerging Economies and the Threat of Financial Collapse. New York: Oxford University Press.

Phillips, P. and Hansen, B.E., 1990. Statistical Inference in Instrumental Variables Regression with I(1) Processes. Review of Economic Studies, 57(1), pp.99-125.

Pinstrup-Andersen, P., 2009. Food security: definition and measurement. Food Security, $1(1)$, pp.5-7.

Post, D.L., 2006. The precautionary principle and risk assessment in international food safety: how the world trade organization influences standards. Risk Analysis, 26(5), pp.1259-1273.

Riès, P., 2000. Asian Storm: The Economic Crisis Examined. North Clarendon: Tuttle Publishing.

Scott, E., 2003. Food safety and foodborne disease in 21 st century homes. The Canadian Journal of Infectious Diseases, 14(5), pp.277-280.

Sima, V. and Gheorghe, I.G., 2015. Changing Consumption Patterns in Green Economy. In: G. Popescu and J.V. Andrei, eds., Agricultural Management Strategies in a Changing Economy - Advances in Finance, Accounting, and Economics. Hershey: IGI Global, pp.186-212.

Strauss, D.M., 2014. Food Security and Safety. In: K. Ludlow, S. Smyth and J. FalckZepeda, eds., Socio-Economic Considerations in Biotechnology Regulation, 37. New York: Springer, pp.109-123.

Turek Rahoveanu, A. and Turek Rahoveanu, M.M., 2013. Socio-economic development prospects of rural areas in the context of application of LEADER Program in Romania. Scientific Papers. Series 'Management, Economic Engineering in Agriculture and rural development', 13(4), pp.295-302.

Zanin, L.M., da Cunha, D.T., de Rosso, V.V., Capriles, V.D. and Stedefeldt, E., 2017. Knowledge, attitudes and practices of food handlers in food safety: An integrative review. Food Research International, 100(Part 1), pp.53-62. 